\title{
The Effect of Mobile Learning Benefits Perception in Supporting Entrepreneurship Apprenticeships Program on Students Entrepreneurship Intention
}

\section{Hendrajaya}

Sekolah Tinggi Ilmu Ekonomi Pariwisata Indonesia (STIEPARI) Semarang

\section{Abstract}

In the Information Technology and Internet Era, Mobile Learning has the potential to support Entrepreneurship Education in Apprenticeship Program. This study aims to test and analysis effect of Mobile Learning Benefits Perception in Supporting Entrepreneurship Education in Apprenticeship Program on Students Entrepreneurship

Corresponding Author: Hendrajaya hjhenjoyo@gmail.com

Received: 7 August 2018 Accepted: 15 September 2018 Published: 22 October 2018

Publishing services provided by Knowledge

(c) Hendrajaya. This article is distributed under the terms of the Creative Commons

Attribution License, which permits unrestricted use and redistribution provided that the original author and source are credited.

Selection and Peer-review under the responsibility of the ICE-BEES 2018 Conference Committee. Intention. The study was conducted by a survey of 140 Final Students at the College of Economics of Tourism in Semarang City who is or has been apprenticed. The benefits of Mobile Learning are measured by students' perceptions of acquiring knowledge, experience and social motivation towards entrepreneurship. The analysis was done by using Structural Equation Modeling (SEM). The result of this research generally finds that entrepreneurship learning through the apprenticeship program and Perception of M-Learning Benefit significantly influence entrepreneur intention either directly or through perceived feasibility and perceived desirability. The total effect of entrepreneurship education in the apprenticeship program has greater path coefficient compared to M-Learning benefit perception, so where M-Learning is only as a supporter of entrepreneurship education in apprenticeship program in increasing students entrepreneurship intention. The results of the study provide the implications of the development of electronic learning through M-Learning in support of entrepreneurial learning. M-Learning, for example, provides independent learning potential, knowledge sharing opportunities, experience sharing, problemsolving based and entrepreneurial motivation facilitate. overcome the problem of busy mentor time in the industrial environment. The results of the study provide implications for the development of M-Learning in supporting entrepreneurial learning such as through curriculum development and learning design.

Keywords: Student Entrepreneurship Intention, Apprenticeships, Mobile Learning 


\section{Introduction}

Globalization, Free Market, Internet Development and Information Technology have an important impact on entrepreneurship education. Free markets provide competition incentives and entrepreneurial opportunities. Free trade demands the availability of highly competent human resources to competitive in the labor market, both regionally, nationally and internationally. The education has the challenge of creating competitive human resources while responding to global opportunities through entrepreneurship development [1]. Universities are faced with challenges to: identify future job profiles, competency requirements, and the ability to adapt and enhance the concept of sustainable education (Wiratno, 2012: 454).

Entrepreneurship education is not a new in Indonesia. The Indonesia Government and related institutions have actually issued policies and programs to reduce educated unemployment and entrepreneurship. The government in Presidential Instruction No. 4, 1995 on "National Movement of Entrepreneurship". At the university level, all universities provide coaching services for entrepreneurship development, but nevertheless entrepreneurial interest in college graduates is still low. The survey results of the Media Group (2015) show that the motivation of Indonesian society (including college graduates) to become entrepreneurs is still very low. The survey results are in line with the results of the National Labor Force 2001 to 2006 (Balitbang, 2010) states that the profile of Indonesian workers is occupied by workers. The number of entrepreneurs is less than one-fifth from the total employee of 25 million people. To the question in the same survey that "the majority of Indonesians want to be what?" Obtained the answer that only $20 \%$ want to become entrepreneurs career.

Apprenticeship as one of the Implementation of Multiple Education Concepts is widely adopted in various countries for the development of entrepreneurship-based education practices [7-9], nevertheless the program apprenticeshipss in Indonesia generally face problems, including mentors in busy industries and unintegrated learning. between learning in the university and the business. Busy time mentors also become obstacles to give students opportunities in obtaining an experience of entrepreneruship

In the information technology era, the use of the internet and information technology such as through the development of electronic learning as in M-Learning has the potential to support the issue of entrepreneurship education in apprenticeships programs [23]. Electronic learning improves the function of guidance, counseling between industry mentors, apprenticeship lecturers and apprentices who emphasize 
the ease of transfer of learning without being tied to the physical location of the learning process (Kukulska-Hulme \& Traxler, 2005). Electronic learning also provides the potential for self-regulated learning, knowledge-sharing opportunities, experience and entrepreneurial motivation facilitate (Dirksen, 2012). Entrepreneurship learning often involves low- and high-level thinking skills as well as a mixture of concrete and abstract knowledge, experience sharing and problem solving with unlimited space and time (Cheong and Cheong, 2012; [23]). Judging from the learning environment, mobile learning facilitates knowledge sharing within the entrepreneurial social community [23].

Based on the description, M-Learning has potential in supporting the weakness of entrepreneurship education in apprenticeships program. This paper is organized into five sections. The next section discusses the literature related to entrepreneur intention, M-Learning and the hypotheses of the study. Methodology, including the sampling, data collection techniques, and measurement methods, is discussed in section 3. Research findings are then presented in the results section, which is followed by implications, and recommendations..

\section{Literature Review}

Entrepreneurship is someone who has the ability to think creatively and behave innovatively to create economic opportunities and seize the opportunities of economic imbalance in competition (through quality competition) in entering growth $[12,29]$. Brown (2000) states that entrepreneurship education should be widely viewed in terms of taught skills and characteristics that can motivate students, thus helping them to seize business opportunities. Hamer (2000) notes that the importance of applying entrepreneurship teaching is more related to field-based methods and less support of classroom-based methods.

An entrepreneurship apprenticeships is a practice-based entrepreneurship education generally conducted by a graduate or fress graduated student as one of the main conditions for completing the educational process. Apprenticeship is a sub-system of training (on the job training) for novice practitioners or professions in the workplace. Much of this training is done while working in an institution / company that provides prentices the opportunity to deepen their skills and improve their "self-selling" after they are rated 'experts' in the field. Apprenticeships participants acquire knowledge, experience and practice opportunities at the apprenticeships, thereby increasing the capability and entrepreneurial interest of apprentices. Apprenticeship has the potential 
as a development of entrepreneurship-based education (experience) to support learning of entrepreneurial (theoretical) courses. In the apprenticeship process, students can acquire new knowledge, new experiences and opportunities to practice the knowledge acquired in college. The new knowledge and experience provide additional references to their perception of the benefits profile and entrepreneurial risks so as to encourage their interest in choosing entrepreneurship as a career choice.

Entrepreneurship learning is not enough to be based on practical experience, but more importantly self-regulated. Entrepreneurship learning involves cognitive, affective, and motivational components. M-Learning is an entrepreneurshiplearning activity undertaken with the help of technology. Electronic learning such as through $M$ Learning has the potential to not only share knowledge, experience and also support self regulated learning.

\subsection{Effect of perceived feasibility on entrepreneurship intention}

Based on Saphero Model $(1975,1982)$ and Krueger (1993), entrepreneurship intention is influenced by the perceived feasibility. Students who think that entrepreneurship is attractive as an economic (income) and psychosocial (autonomous, self regulated) career choice will have an interest in choosing a career as an entrepreneur compared to other jobs. In contrast, students who consider entrepreneurship to be unattractive as an economic career option (for earning income) and risky have no interest in choosing a career as an entrepreneur and choosing other jobs.

Previous research on the influence of the perception of eligibility to entrepreneurship intentions found diverse results. Some of the research as conducted by Segal, et. al (2005), Buelens (2008), Linan et al. (2011), Karimi (2012), Liñán and Chen (2006), Wang et al. (2011), Weerakoon and Gunatissa (2014), AlHaj et al. (2011) found that the perception of eligibility affects entrepreneur interest. Other studies as conducted by AlHaj et al. (2011) find different results that the perception of eligibility has no effect on entrepreneurship intention. Some of the other studies as conducted by Segal, et. al (2005), Liñán and Chen (2006), Wang et al. (2011), Weerakoon and Gunatissa (2014), AlHaj et al. (2011) found out that both the perceived feasibility and perceived desirability have an effect on entrepreneurship intention, but the influence of perceived desirability on entrepreneur intention is greater than the influence of perception of eligibility to entrepreneur intention. Hypothesis in this research can be formulated as follows. 
H1. Perceived Feasibility positively affects on student entrepreneurship career intention

\subsection{Effect of perceived desirability on entrepreneurship intention}

According to Saphero Model $(1975,1982)$ and Krueger (1993), entrepreneurial intention is not only influenced by the perceived feasibility but also the perceived desirability. The perceived desirability is a manifestation of self-efficacy measured by the belief that it will succeed in entrepreneurship, belief in ability, confidence through obstacles. Students who have confidence in the ability to entrepreneurship, confidence through barriers, confidence to succeed to entrepreneur will have an interest to choose a career as an entrepreneur than any other work. Conversely, students who are unsure of ability, unsure of being able to go through obstacles, unsure of being successful in berwirauasaha have no interest in choosing a career as an entrepreneur and choosing other jobs.

Previous research on the influence of perceptions of desire on entrepreneurship intentions tends to yield consistent results. Some research $([4,11,13,21,24]$; Küttima, et al., 2014; $[11,30])$ found that the perceived desirability affects entrepreneurship intention. Several studies in recent years $([4,11,13,21,24]$; Küttima, et al., 2014; [11, 30]) finds the effectiveness of entrepreneurship education in enhancing entrepreneurship intention through perceived feasibility and perceived desirability. Several studies as conducted by Segal, et. al (2005), Liñán and Chen (2006), Wang et al. (2011), Weerakoon and Gunatissa (2014), AlHaj et al. (2011) has found that perceived desirability has a greater influence on entrepreneurship intention than perceived feasibility. Hypothesis in this research can be formulated as follows.

H2. Perceived Desirability has a positive effect on Students Entrepreneurship career intention

\subsection{Effect of entrepreneurship apprenticeships program on perceived feasibility}

According to Saphero Model $(1975,1982)$ and Krueger (1993), Entrepreneurship education has no direct effect on entrepreneurship interest but through perception of feasibility and perception of desire. Entrepreneurship education through apprenticeship program is an external factor that provides entrepreneurial knowledge and experience 
so as to influence attitudes and subjective norms that careers as entrepreneurs are economically and socially viable as employees.

Previous studies ([11, 21, 24]; Küttima, et al., 2014) on the influence of entrepreneurship education on feasibility perceptions found diverse results. Some studies have found that entrepreneurship education has an effect on perceptions of entrepreneurship worthiness. Other studies found different results that entrepreneurship education has no effect on the perception of entrepreneurship feasibility but more influence the perception of desire.Hypothesis in this research can be formulated as follows.

H3.Entrepreneurship Apprenticeships Program has a positive effect on Perceived Feasibility

\subsection{Effect of entrepreneurship apprenticeships program on perceived desirability}

According to Saphero Model $(1975,1982)$ and Krueger (1993), entrepreneurship education in addition to the influence of entrepreneurship interests through the perception of feasibility also affects entrepreneurship interests through the perception of desire. Entrepreneurship education through an internship program provides knowledge and experience about entrepreneurship better thus affecting the belief that students can start new ventures and manage opportunities and entrepreneurial barriers as career options.

Prior research $([11,21,24]$; Küttima, et al., 2014) generally finds that the perception of desire is an important factor on the influence of entrepreneurship education on perception of desire found diverse results. Some studies have found that entrepreneurship education has an effect on perceptions of entrepreneurship worthiness. Other studies found different results that entrepreneurship education has no effect on the perception of entrepreneurship worthiness bnamun more influence perception of desire.ypothesis in this research can be formulated as follows.

H4. Entrepreneurship Apprenticeships Program has a positive effect on Perceived Desirability 


\subsection{Effect of entrepreneurship apprenticeships program on entrepreneurship cerrer intention}

Apprenticeships has the potential to develop a practical entrepreneurship education (experience) to support the learning of entrepreneurial (theoretical) courses. In the apprenticeship process, tourism students can acquire new knowledge, new experiences and opportunities to practice knowledge acquired in college. The new knowledge and experience provide additional references to their perception of the benefits profile and entrepreneurial risks so as to encourage their interest in choosing entrepreneurship as a career choice.

Prior research $([11,21,24]$; Küttima, et al., 2014) on the effectiveness of entrepreneurship education found mixed results. Some studies have found the effectiveness of entrepreneurship education to develop entrepreneurship interests, but other studies have found different results that entrepreneurial education is ineffective in developing entrepreneurial interests.

Hypothesis in this research can be formulated as follows.

H5. Entrepreneurship Apprenticeships Program has a positive effect onstudent entrepreneurship career intention

\subsection{Effect of M-learning benefits perception on entrepreneurship intention}

The development of information and internet technology has the potential as a development of entrepreneurship education to support the learning of entrepreneurial (theoretical) courses and experience-based through apprenticeship. The Internet can increase knowledge about entrepreneurship, facilitate sharing experiences, facilitate the sensial influence, motivate students about entrepreneurial career. The new knowledge and experience provide additional references to their perception of the benefits profile and entrepreneurial risks so as to encourage their interest in choosing entrepreneurship as a career choice.

In the era of information technology, the use of the Internet and information technology has the potential to support entrepreneurship education issues [23]. First, the use of internet and information technology enhances the guidance function that emphasizes the ease of transfer of learning process without being tied to the physical location of the learning process. Second, the use of internet and information technology supports effective learning design. Entrepreneurship learning activities often involve 
low and high thinking skills as well as a mix of concrete and abstract knowledge, experience sharing and problem solving that are not limited space and time. Third, in terms of the learning environment, the use of the Internet and information technology facilitates the sharing of knowledge within the entrepreneurial social community [23]. Luckin and Noss (2012) found that digital learning (e-learning) on the one hand is difficult and risky, but on the other hand provides benefits in supporting learning processes both outside and in the classroom. Luckin and Noss (2012) also found that technology can be used for knowledge and skill assessment. Previous studies have generally found that M-Learning-based learning is effective in improving students' abilities such as: problem-solving performance [25], learning process (Clark and Killingsworth, 2014), learning long distance (Clark and Killingsworth, 2014). However, previous research is limited to discuss the benefits of M-Learning for entrepreneurial learners. Hypothesis in this research can be formulated as follows.

H3. Perception of M-LearningBenefits has a positive effect on student entrepreneurship career intention

\subsection{Effect of M-learning benefits perception on perceived feasibility}

Theory of Cognitive Behavior ([2, 3, 6]; Shapero, 1986) explains that there is a relationship between individual, social, and environmental behavior. The cognitive paradigm has also dominated the study of learning, and uses the concept of processing individual information to understand the human mind and the ability to learn [6]. Based on the Krueger (1993) model, external factors such as the internet provide individual cognitive stimuli that ultimately influence behavioral responses. Internet access activity is an external factor that provides knowledge, experience and entrepreneurial motivation to improve understanding of the feasibility of entrepreneurship benefits such as the benefits of better income opportunities, the opportunity to create jobs for both yourself and others and the benefits of autonomy. Entrepreneurship education through the apprenticeship program also provides a real student experience that ultimately can improve the perception of entrepreneurship feasibility that ultimately can increase interest and entrepreneurship behavior.

Prior research ([11, 21, 24]; Küttima, et al., 2014) found the effect of entrepreneurship education on the perception of entrepreneurship eligibility. Entrepreneurship education through apprenticeship programs is an external factor that provides entrepreneurial knowledge and experience so as to influence subjective attitudes and 
norms that careers as entrepreneurs are economically and socially viable as employees. However, the study has not specifically addressed the electronic mentoring aspect in entrepreneurship education. Hypothesis in this research can be formulated as follows.

H4. Perception of M-LearningBenefits has a positively affects on the Perceived Feasibility

\subsection{Effect of M-learning benefits perception on perceived desirability}

Based on model framework Krueger (1993), mentoring activity in apprenticeships program besides affecting entrepreneurship intention through perceived feasibility also influence to entrepreneurship intention through perceived desirability. The mentoring activities in the apprenticeships program provide tuition of knowledge, experience and entrepreneurial motivation thus affecting the belief that students can start new ventures and manage opportunities and entrepreneurial barriers as career options.

Prior research ([11, 21, 24]; Küttima, et al., 2014) found that entrepreneurship education influenced perceptions of entrepreneurship desire. The development of gadget equipment supports the mobile Internet, which is easy to carry anywhere, so that communication is increasingly unlimited space and time. The development of information and internet technology is potential in supporting entrepreneurship education in apprenticeship programs, especially to overcome the problems of mentors in busy companies and problem-based learning (Problem solving) in entrepreneurship education. Previous research is still limited which discusses M-Learning good to the perception of eligibility, perceived desirability and entrepreneur interest. Relating to the perception of belief, $M$-Learning provides benefits in supporting entrepreneurship Education in apprenticeship programs that facilitate the transfer of experience, knowledge and motivation so as to increase confidence in starting new ventures and confidence to succeed in managing obstacles and success in berwirausaaha. Hypothesis in this research can be formulated as follows.

$\mathrm{H}_{5}$. Perception of M-LearningBenefits has a positive effect on the Perceived Desirability 


\section{Research Methods}

This research is done to the final grade students of one university in Semarang Indonesia who are or have been followed on job training (apprenticeships) in industry. Data of M-Learning, perceived feasibility, perceived desirability, entrepreneurship intention in the form of primary data collected through questionnaire. Data collection activities are conducted for 2 (two) months, from November to December 2017.

TABLE 1: Variables and Indicator.
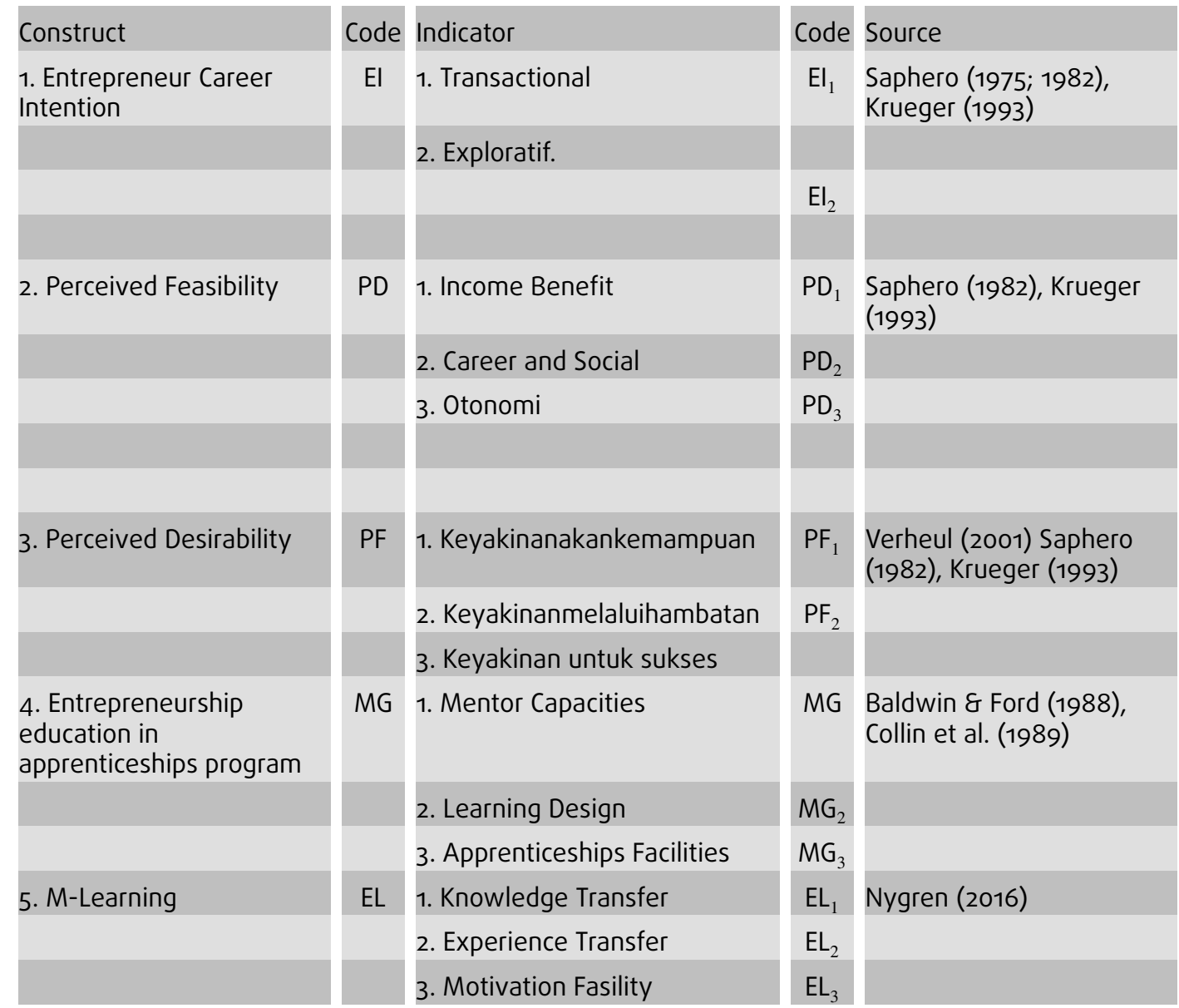

Data analysis was done by using Structural Equation Modeling (SEM). Testing model through testing of structural equation and measurement test of construct. The structural equation consists of three models as follows.

$$
\begin{gathered}
Z P F=\beta_{1.1} M G+\beta_{1.2} E L+\epsilon 1 \\
Z P D=\gamma_{1.1} M G+\gamma_{1.2} E L+\epsilon 2 \\
Z E I=\delta_{1.1} M G+\delta_{1.2} E L+\delta_{1.3} P F+\delta_{1.4} P D+\epsilon 3
\end{gathered}
$$


Where: $\beta, \gamma, \delta=$ path coefficient, $\epsilon=$ error. The measurement model is the relationship between an indicator or a manifest with its latent construct. In this SEM analysis, there is no single statistical test to test the model hypothesis (Hair et al., 1998), but the various fit indexes used to measure the degree of conformity between the presented model and the data presented. The fit index used includes. Chi Square, Normed Chi Square (CMIN/DF), Goodness Of Fit Indeks (GFI), Adjusted Goodness Fit of Index (AGFI), Tucker Lewis Index (TLI), Normed Fit Index (NFI), Comparative Fit Index (CFI), Root Mean Square Error of Approximation (RMSEA).

\section{Result}

\subsection{Descriptive of variables}

The results of this study generally find that the entrepreneurship intention of lower adult students. The perception of entrepreneurship feasibility tends to be rather high, but the perception of entrepreneurial desire is rather low. Student perceptions of M-Learning tend to be rather low. Viewed from the interests of entrepreneurship, entrepreneurship intention as a career choice is rather low both in aspects of transactional interest and exploration interest. Most respondents (16.07\%, Table 2 ) rate rather disagree about the opportunity of entrepreneurship benefits higher than the risk of making entrepreneurship as a career choice. Most respondents rate rather disagree that the benefits of entrepreneurship as a career choice better than other professions.

The feasibility perception is rather high, but the perceived desirability is rather low. In fact, students have considered that entrepreneurship deserves or provides economic benefits, career and autonomy, but they tend to be less confident in ability, less confident of going through obstacles or less sure of success in entrepreneurship, especially in a dynamic and uncertain environment. Most of the students ( $76.43 \%$, see Table 2 ) have a negative perception of the perceived desirability as measured by the belief in self-efficacy. Most of the students (75.71\%) have a perceived desirability as measured by the belief will succeed if making entrepreneurship as career choice. External factors such as the uncertainty of business environments make the challenge of entrepreneurship and make some students unsure of succeeding to make entrepreneurship as a career choice.

The development of information and internet technology has the potential to support entrepreneurship education in apprenticeships activities. Currently there is no electronic-based entrepreneurship mentoring curriculum, however, a small portion 
TABLE 2: Distribution of Frequency and Average Score of Research Variables.

\begin{tabular}{|c|c|c|c|c|c|c|c|c|}
\hline \multirow[t]{2}{*}{ Variable } & \multicolumn{6}{|c|}{ Frequency } & \multirow[t]{2}{*}{ Mean } & \multirow[t]{2}{*}{ Category } \\
\hline & 1 & 2 & 3 & 4 & 5 & 6 & & \\
\hline $\begin{array}{l}\text { Entrepreneurship Education in } \\
\text { Apprenticeships Program }\end{array}$ & - & 4 & 114 & 237 & 43 & 22 & 3.92 & AT \\
\hline M-Learning Benefit Perception & 2.9 & 30.7 & 42.6 & 18.6 & 4.0 & 1.2 & 2.94 & AR \\
\hline Perceived Feasibility & - & 2.4 & 28.6 & 43.1 & 20.5 & $5 \cdot 5$ & 3.98 & AT \\
\hline Perceived Desirability & 1.0 & 17.6 & 62.6 & 11.0 & 6.0 & 1.9 & 3.09 & AR \\
\hline Entrepreneur Intention & - & 12.5 & 67.5 & 16.1 & 2.5 & 1.4 & 3.13 & AR \\
\hline \multicolumn{9}{|c|}{$\begin{array}{l}\text { Note: } \\
1 \text { to } 1.83=(1) \text { very low / very not agree } \\
1.84 \text { to } 2.67=(2) \text { low / disagree } \\
2.67 \text { to } 3.5=(3) \text { rather low / slightly disagreeable } \\
3.51 \text { to } 4.33=(4) \text { (rather high / somewhat agree } \\
4.33 \text { to } 5.17=(5) \text { high / agree } \\
5,217 \text { to } 6=(6) \text { very high / strongly agree } \\
\text { Source: Analysed from questionnaire }(2016)\end{array}$} \\
\hline
\end{tabular}

(23.8\%) of mentors in industry and students have used communication and internet media for mentoring activities. Student perceptions of the use of electronic media for mentoring activities as in sharing knowledge, sharing experiences and motivating entrepreneurial means to students tend to be rather low (average $=2.94$ ).

All student respondents have gadget equipment (smartphone, tablet, notebook / laptop) that can be used for internet access. At this time easier access to the internet especially in urban areas such as the city of Semarang. Students can access the internet either through gadget equipment, or via the internet. Students generally access the internet from: gadget equipment (such as pc, mobile phone, smart phone, tablet, notebook) (100\%), internet facilities on campus (8.57\%), internet cafes (85.71\%) and others like at work (for students already working) (2.86\%). Although on campus has provided hotspot area, but not all students can take advantage of the facility, because only a small part of the students who have their own gadget equipment.

The study also revealed that $32.8 \%$ percent of respondents use computers to access the internet. As many as 59.29\% use notebook / laptop. More than half of respondents (55.7\%) use mobile phones to access the internet, and only $6.3 \%$ use tablets. Most of the students use the internet to search information related to the lecture tasks $(69.29 \%)$, to connect with friends (old and new) $(88.57 \%)$, seek information other than college assignment (24.29\%), and to entertainment (32.14\%). Information searching is often driven by schoolwork, while the use of social media and entertainment content is driven by personal needs. Many of us students use the Internet as a supporter of our learning activities, for example by finding sources of learning and articles related 
TABLE 3: Internet Access Activity by Student

\begin{tabular}{|c|c|c|c|}
\hline \multicolumn{2}{|c|}{ Description } & Frekuensi (n) & Persen $(\%)$ \\
\hline \multicolumn{4}{|c|}{ Do you often use the internet in a day } \\
\hline$\square$ & often & 102 & 72.86 \\
\hline$\square$ & гаге & 38 & 27.14 \\
\hline \multirow[t]{2}{*}{$\square$} & never & 0 & 0.00 \\
\hline & & 140 & 100.00 \\
\hline \multicolumn{4}{|c|}{ How long do you connect to the internet in a day: } \\
\hline$\square$ & $>40$ hours / month & 94 & 67.14 \\
\hline$\square$ & 10 s.d 40 hours / month & 34 & 24.29 \\
\hline \multirow[t]{2}{*}{$\square$} & $<10$ hours / month & 12 & 8.57 \\
\hline & & 140 & 100.00 \\
\hline \multicolumn{4}{|c|}{ You access the internet from: } \\
\hline$\square$ & gadget equipment & 140 & 100.00 \\
\hline$\square$ & internet facility on campus & 12 & 8.57 \\
\hline$\square$ & internet cafe & 120 & 85.71 \\
\hline$\square$ & others & 4 & 2.86 \\
\hline \multicolumn{4}{|c|}{ Do you have gadget equipment (seperti: smartphone, tablet, notebook) } \\
\hline \multirow{2}{*}{\multicolumn{2}{|c|}{$\square$ Yes }} & 140 & 100.00 \\
\hline & & & 0.00 \\
\hline \multicolumn{2}{|c|}{ Kind of gadget equipment owned: } & & 0.00 \\
\hline$\square$ & smartphone & 78 & 55.71 \\
\hline$\square$ & tablet & 9 & 6.43 \\
\hline$\square$ & notebook/laptop & 83 & 59.29 \\
\hline$\square$ & pc & 46 & 32.86 \\
\hline \multicolumn{4}{|c|}{ Activities you do in accessing the internet: } \\
\hline$\square$ & doing college assignments & 97 & 69.29 \\
\hline$\square$ & entertainment & 45 & 32.14 \\
\hline$\square$ & connect with social community & 124 & 88.57 \\
\hline$\square$ & seek information other than college assignments & 34 & 24.29 \\
\hline \multicolumn{4}{|c|}{ Source: Analysed from questionnaire (2016) } \\
\hline
\end{tabular}

to the lessons we are studying. Most students use the internet for college assignments, social connections, entertainment, little entrepreneurial access (knowledge of business opportunities, entrepreneurial experience, financial management, new product information, new markets) The results generally find that students' perceptions of the benefits of mobile internet over this for access to information, knowledge, experience and entrepreneurial motivation is still rather low (Table 3). Most students use the mobile internet to do lectures (69.29\%), to connect with friends (old and new) $(88.57 \%)$, to seek information other than college assignments (24.29\%), and 
for entertainment $(32,14 \%)$, but limited in access to information, knowledge and entrepreneurial experience (Table 3). '

The results of the study found that most students often use the internet in daily life $(72.86 \%)$, while the students who rarely use the internet only $27.14 \%$. Most of the students included in Heavy users $(67.14 \%)$ ie internet users spend more than 40 hours per month. This type of internet user is one of the characteristics of addicted internet users. Users with the category Medium users: Internet users who spend between 10 to 40 hours per month as much as $24.20 \% 9 \%$, while Light users are internet users who spend less than 10 hours per month only $8.57 \%$.

\subsection{Hypothesis testing}

The endogenous confirmatory confirmatory factor analysis aims to test the unidimensionality of endogenous latter variable (endogenous) reflector indicators. These latent variables or endogenous constructs consist of 3 unobserved variables with 8 observed variables as their reflector. The value of Standardized Regression Weights is above 0.5 (Table 4), so it is concluded that all reflector indicators of latent variables are significantly indicators of latent factors that are reflected. Measurement of construct reliability using Construct Reliability and Variance Extracted. cut-off value of Construct Reliability of at least 0.70, while the cut-off value of Variance Extracted is at least 0.50 .

The results of the feasibility test of the research model for SEM analysis in Table 4 above show that all goodness of fit criteria are acceptable which means the model is good (Hair, et al., 1995). Overall, the test results are chi-square of 60.998, probability of 0.714 (>0.05), GFI of 0.940 (> 0.80), AGFI of 0.908 (>0.8), TLI of 1.006 (> 0.95), CFI of 1,000 ( $>0.95)$, CMIN / DF of $0.897(<2.00)$, and RMSEA of $0.000(<0.080)$. Table 4 shows a summary of the SEM output results and the suggested values for measuring the fit (fit) model. As shown in Table 4 it also illustrates that almost all instructions in the model have met the recommended value. Thus, the final model developed is fit (fit) with the data. Overall the model is acceptable and the next step analyzes

Based on Table 6, all hypotheses are proved. M-Learning has a significant effect on the feasibility perception variable, with $C R=1.851$ above 1.96 with $P$ less than 0.10 . $M$ Learning has a significant effect on the variables of perceived desirability (PD), with the value of $C R=1.955$ or above 1.96 with $P$ smaller than 0.05 . M-Learning, perceived feasibility and perceived desirability have a significant effect on endogenous variable of entrepreneurship intention, with $C R$ value above 1,96 with $P$ smaller than 0,05. Variable and $M$-Learning have significant effect to entrepreneurship intention variable, 
TABLE 4: Constructive Reliability Test Results .

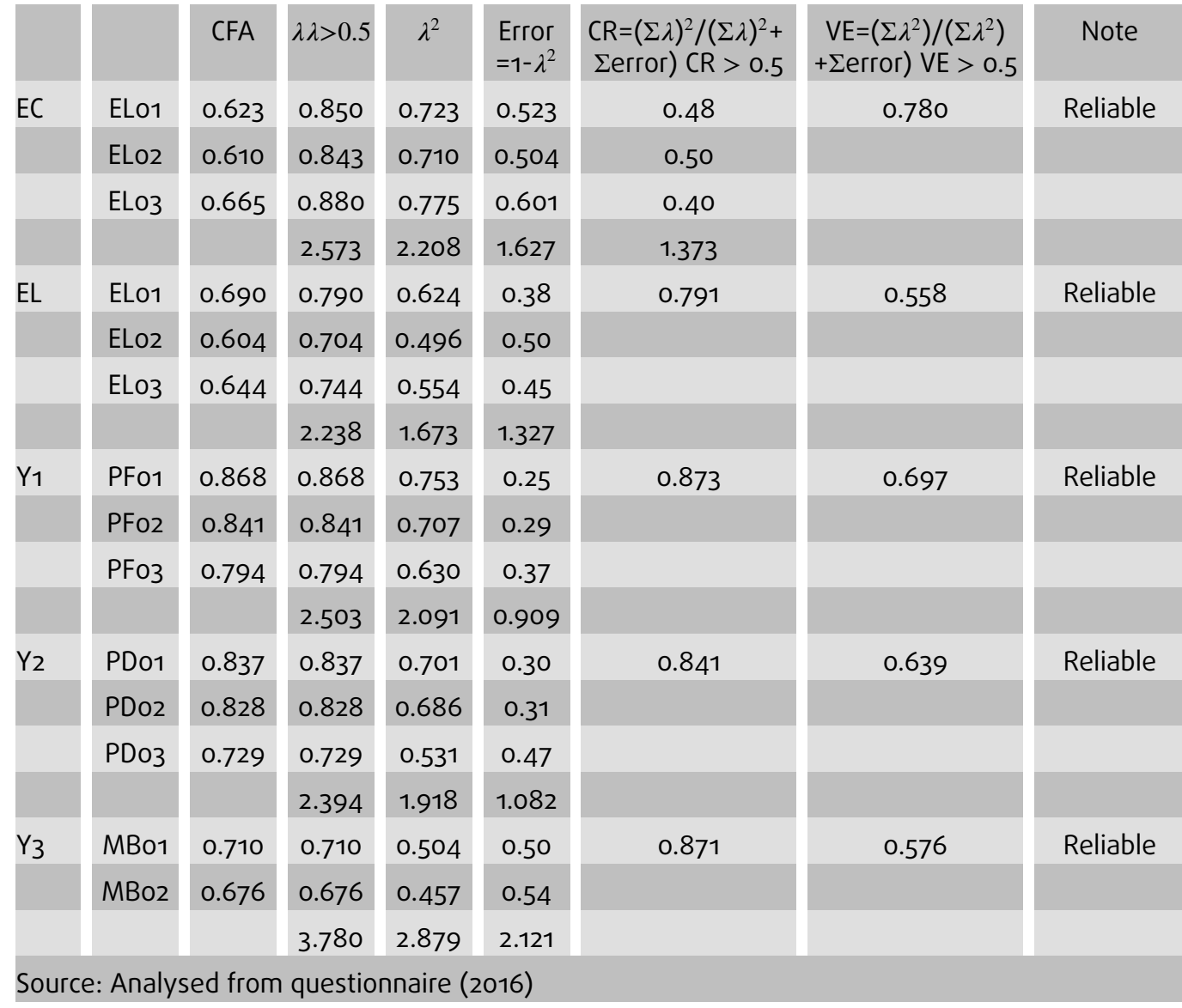

TABLE 5: Model Fit.

\begin{tabular}{l|c|c|c|}
\hline $\begin{array}{l}\text { Criteria } \\
X^{2} \text {-Chi-Square } \\
(D F=371, p=0,05)\end{array}$ & $>646$ & 60.998 & Fit \\
\hline Sig. Probability & & & \\
\hline CMIN/DF & $>0.05$ & 0.714 & Fit \\
\hline GFI & $<2.00$ & 0.897 & Marginal Fit \\
\hline AGFI & $>0.90$ & 0.94 & Fit \\
\hline TLI & $>0.90$ & 0.908 & Fit \\
\hline CFI & $>0.90$ & 1.006 & Fit \\
\hline RMSEA & $>0.90$ & 1 & Fit \\
& $<0.05$ & 0 & Fit \\
\hline Source: Analysed from questionnaire (2016) & &
\end{tabular}

with value of $C R=2,108$ above 1,96 with $P$ smaller than 0,10. Variable perceived feasibility have significant effect to entrepreneurship intention variable, with value of $C R=1,719$ above 1,96 with $P$ smaller than 0,10 . The variables of perceived desirability have a significant effect on the entrepreneurship intention variable, with the value of $C R=3.218$ above 1.96 with $P$ smaller than 0.10 . 


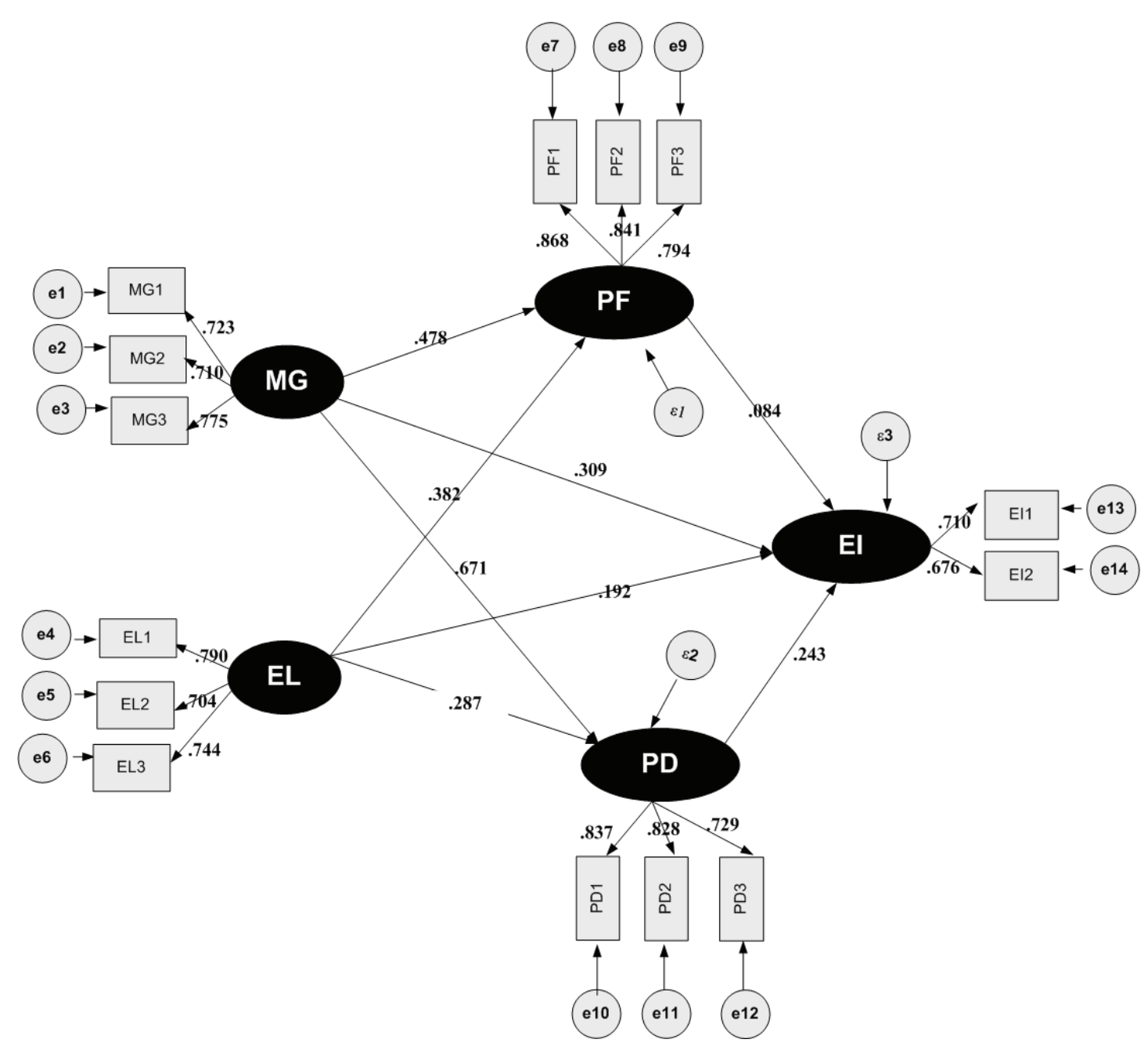

Figure 1: Structural Equation Model test. Source: Analysed from questionnaire (2016).

\section{Discussion}

Cognitive behavior theory (Bandura, 1964; Fishebein, 1085; Shapero, 1986) explains that there is a relationship between individual, social, and environmental behavior. The cognitive paradigm has also dominated the study of learning, and uses the concept of processing individual information to understand the human mind and the ability to learn (Bandura, 1989). Environment and social in this case can be an environment in the virtual world (internet). Shapero-based models (1986) external factors such as the internet provide individual cognitive stimuli that ultimately influence behavioral responses. Based on this model, knowledge, experience and social motivation from the internet affect the perception of eligibility, perceived desirability and interest in behavior.

The results generally find that the perception of entrepreneurship eligibility as a career choice is rather high in terms of income benefits compared to other professions, 
TABLE 6: Regression Result.

\begin{tabular}{|c|c|c|c|c|c|}
\hline & & & $\begin{array}{l}\text { Total } \\
\text { Effect }\end{array}$ & $\mathrm{CR}$ & $p$ \\
\hline Perceived feasibility & $<-$ & $\begin{array}{l}\text { Entrepreneurship } \\
\text { Apprenticeships }\end{array}$ & 0.478 & 2.632 & 0.008 \\
\hline Perceived Desirability & $<-$ & $\begin{array}{l}\text { Entrepreneurship } \\
\text { Apprenticeships }\end{array}$ & 0.671 & 3.750 & 0.000 \\
\hline $\begin{array}{l}\text { Entrepreneur Career } \\
\text { Intention }\end{array}$ & $<-$ & $\begin{array}{l}\text { Entrepreneurship } \\
\text { Apprenticeships }\end{array}$ & 0.309 & 2.505 & 0.012 \\
\hline Perceived feasibility & $<-$ & M-Learning & 0.382 & 1.851 & 0.064 \\
\hline Perceived Desirability & $<-$ & M-Learning & 0.287 & 1.955 & 0.051 \\
\hline $\begin{array}{l}\text { Entrepreneur Career } \\
\text { Intention }\end{array}$ & $<-$ & M-Learning & 0.192 & 2.108 & 0.035 \\
\hline $\begin{array}{l}\text { Entrepreneur Career } \\
\text { Intention }\end{array}$ & $<-$ & Perceived feasibility & 0.084 & 1.719 & 0.086 \\
\hline $\begin{array}{l}\text { Entrepreneur Career } \\
\text { Intention }\end{array}$ & $<-$ & Perceived Desirability & 0.243 & 3.218 & 0.001 \\
\hline
\end{tabular}

career and social benefits and benefits of autonomy (Table 6). Most of the respondents (69.04\%) (Table 6) considered that entrepreneurship provides higher income opportunity opportunities than other professions, creates employment at least for themselves and provides autonomy in managing time and resources.

The results of this study found that the perceived feasibility and desire perceptions have a positive and significant impact on entrepreneur interest. The results of this study support the Shapero model (1986), that entrepreneurship intention is influenced by perceived feasibility and perceived desirability. If a career as an entrepreneur is economically and socially viable than any other profession, then the individual will tend to be interested in choosing entrepreneurship as a career option compared to other professions. Conversely, if the career as an entrepreneur is not / less economically and socially viable than other professions, then individuals will tend to be interested in choosing other professions and are not interested in making entrepreneurship as a career choice. Such research is done by Segal, et. al (2005), Buelens (2008), Linan et al. (2011), Karimi (2012), Liñán and Chen (2006), Wang et al. (2011), Weerakoon and Gunatissa (2014), found that the perception of eligibility affects entrepreneur interest.

Entrepreneurship intention is not only influenced by the perception of eligibility, but also the perceived desirability, even some research as conducted by Segal, et. al (2005), Liñán and Chen (2006), Wang et al. (2011), Weerakoon and Gunatissa (2014), AlHaj et al. (2011) finds the result of perceived desirability influence bigger to entrepreneur interest compared to influence perceived feasibility to entrepreneurship intention.. Individuals will choose entrepreneurship as a career choice not only just a 
rational consideration of the feasibility but also the desire. Perceived desirability is a manifestation of self-belief (optimism) that he will succeed to entrepreneurship. 'The belief is in the form of confidence to start a new business, confidence to overcome obstacles, as well as confidence in the ability of self in managing the business. If the individual is sure to be successful for entrepreneurship, then the individual will tend to be interested to choose entrepreneurship as a career option than any other profession. Conversely, if the individual is not sure will succeed to entrepreneurship, then the individual will tend to choose other professions and not interested to make entrepreneurship as a career choice.

External environments such as entrepreneurship education provide entrepreneurial knowledge, experience and motivation. The mentoring activity through electronic media support (M-Learning) provides the benefits of knowledge sharing, experience sharing, and motivating apprenticeships facilities that can be done anytime and anywhere, so M-Learning can improve the feasibility and desire that ultimately increase entrepreneurship intention. Mentoring through electronic media (M-Learning) overcomes the mentor's time in a busy company. The development of information and internet technology has the potential as a development of entrepreneurship education to support the learning of entrepreneurial (theoretical) courses and practice-based (experience) through apprenticeship (0JT). The Internet can increase knowledge about entrepreneurship, facilitate the sharing of knowledge and experience, facilitate social influences, motivate students about entrepreneurial career. The new knowledge and experience provide additional references to their perception of the benefits profile and entrepreneurial risks so as to encourage their interest in choosing entrepreneurship as a career choice.

Previous research has generally found that digital-based learning is effective in improving students' abilities such as: problem-solving performance [25], learning process (Clark and Killingsworth, 2014), distance learning (Clark and Killingsworth, 2014). But researchers which was previously limited to discuss the benefits of $M$-Learning for entrepreneurial learners. The results of this study found the effect of student perception on M-Learning on entrepreneurship intention (Table 6). The results of this study are not only in the aspects of problem-solving performance [25], the learning process (Clark and Killingsworth, 2012) learning outcomes (Clark and Killingsworth, 2014) but also implies that M-Learning is effective in increasing student entrepreneurship intention. Students actually use the internet frequently to help with college assignments, connecting with social communities, information and entertainment but low to access entrepreneurial knowledge and experience. In addition to the potential to increase 
self regulated learning, M-Learning can help to overcome the problems of mentor busyness, unlimited discussion and motivation of space and time, and facilitate pengatahuan, sharing experiences more easily. Based on Table 2, the majority of students $(69.29 \%)$ have a positive attitude that entrepreneurship can have an opportunity to earn more income, but the risk is also greater. Most students (68.57\%) also have a positive attitude that entrepreneurship can also provide job opportunities, autonomy of freedom in managing time and finances. However, most students (69.29\%) have a negative attitude that entrepreneurship gives greater uncertainty. Working in a private company as an employee has a better stability guarantee. Greater risk in a dynamic industry environment and uncertainty. Shapero-based model (1986), explains that mobile internet-based entrepreneurship education has no direct effect on entrepreneurship intention but through perceived feasibility and perceived desirability. The knowledge, experience and social motivation of entrepreneurship from the mobile internet is an external factor that enhances the understanding of the feasibility of entrepreneurial benefits as it relates to the feasibility of benefiting better income opportunities, the opportunity to create jobs for both yourself and others and the benefits of autonomy. However, research that examines the effect of mobile internet based entrepreneurship education on entrepreneurship eligibility is still limited. The results of this study found that students' perceptions of $M$-Learning have an effect on perceived feasibility and perceptions of entrepreneurship desire (Table 6). Students who have intensity more often in getting exposure of knowledge, experience and motivation from mentor through electronic media media will be diringi with higher perception of benefits of entrepreneurship eligibility as a career choice both benefits of income opportunities, career benefits and autonomy and belief belief in ability, confidence through obstacles and conjectures will succeed in entrepreneurship. Belief in ability, confidence through obstacles and conjectures will succeed in entrepreneurship is an indicator in the variable perceived desirability. However, most students (70\%) have a negative perceived desirability in the form of self-confidence will be successful in entrepreneurship. most of the students have negative perception towards perceived desirability $(76,43 \%)$ as measured by self confidence. These entrepreneurial barriers include the ability of capital and market access. Some respondents considered that although a lot of capital offered by banks during this time, but not necessarily new entrepreneurs will easily gain access to capital. Although many unsecured loans are guaranteed by the government as in the form of microcredit, in practice new entrepreneurs still need to have collateral and already have a business. This becomes a new entrepreneur obstacle. Secondly, most students $(75.00 \%$, see Table 
6) have a negative perception of perceptions of entrepreneurship desire as measured by beliefs will succeed through obstacles in entrepreneurship. Most students have a rather low confidence will succeed through the barriers in starting entrepreneurship. Most of the students have a rather low confidence will succeed through the barriers in managing entrepreneurship. Thirdly, most students (75.71\%, see Table 2 ) have a negative perception of entrepreneurship perceptions as measured by the beliefs that will succeed if they make entrepreneurship as a career choice. External factors such as the uncertainty of the business environment make the challenge of entrepreneurship and make sebgaian students unsure will succeed to make entrepreneurship as a career choice. A small percentage of respondents ( $18.81 \%$, see Table 2 ) have a positive perceived desirability. A small percentage of students have a negative perception of the perceived desirability.

\section{Conclusion}

The results of the study generally found that entrepreneurship learning through the apprenticeship program and Perception of M-Learning Benefit significantly on entrepreneurship intention either directly or through the perceived feasibility and the perceived desirability for entrepreneurship as career choice. The results of this study provide important implications in the development of electronic learning such as through M-Learning in entrepreneurship education. Mentoring through electronic media (M-Learning) overcomes the mentor's time in a busy company. M-Learning provides the benefits of sharing knowledge, sharing experiences, and motivating means of apprenticeships that can be done anytime and anywhere, so M-Learning can improve the feasibility and desire that ultimately increase entrepreneurship intention. The results of this study also provide the implications of curriculum development, syllabus containing M-Learning material in support of entrepreneurship education in apprenticeship programs that are not currently available.

This study has several limitations. The research was conducted by survey approach. Survey research has a weakness over a period of time. Research results may change with time (technology, social, culture, policy), so further research is needed, along with technological, social, cultural, policy developments. This research has not included geographical area factor, for example because of technology infrastructure, social, culture. The research also has not included factors faculty differences, GPA, family entrepreneurship. Incorporating several factors in the model can enrich the research results.. 


\section{References}

[1] Abele, E., Metternicha, J., Tischa, M., Chryssolouris, G., Sihnc, W., ElMaraghy, H., Hummele, V., Ranze, F. (2015). Learning Factories for research, education, and training. Procedia CIRPVol. 32, pp. 1 - 6

[2] Ajzen, I. and M. Fishbein, (1975). The Prediction of Behavior from Attitudinal and Normative Variables. Journal of Experimental Social Psychology Vol. 6, pp. 166-88.

[3] Ajzen, I. (1991). The theory of planned behaviour. Organizational behavior and human decision makingVol. 50 No. 2, pp. 179-211.

[4] AlHaj, B.K., Yusof, M.Z., Edama, N. (2011). Entrepreneurial Intention: An Empirical Study of Community College Students in Malaysia. JurnalPersonaliaPelajar, BilVol. 14, pp. $45-58$

[5] Badan Penelitian dan Pengembangan (2010). Laporan Hasil Penelitian Alternatif Pelaksanaan Pendidikan Kewirausahaan di Perguruan Tinggi, bekerjasama dengan Universitas Negeri Jakarta, Kemdiknas, Jakarta.

[6] Bandura, 1961. Imitation of Film Mediated Aggressive Models. Journal of Abnormal and Social Psychology. Vol. 66 No. 1, Pp. 3-11

[7] Bliem, W.,Schmid, K.,Petanovitsch, A. (2014). Success factors for the Dual VET System: possibilities for know-how-transfer.Wien:InstitutfürBildungsforschung der Wirtschaft, Literaturverz., 177. http://www.ibw.at/components/com_redshop/ assets/document/product/1404280103_fb177_en.pdf [Diakses 21.12.2014]

[8] Eichhorst, W., Rodriguez-Planas, N., Schmidl, R., Zimmermann, K.F. Bonn,. (2014) A roadmap to vocational education and training around the world. Literaturverz. 42http://www.iza.org/conference_files/worldb2014/1551.pdf [Diakses 12.12.2015]

[9] Euler, D., Gütersloh, Stiftung, B. (2013). Germany's dual vocational training system: a model for other countries? Literaturverz., Abb., http: //www.bertelsmann-stiftung.de/cps/rde/xbcr/SID-ED1DBC2EEC8835F9/bst/ xcms_bst_dms_37644_37778_2.pdf [Diakses 30.12.2013]

[10] Instruksi Presiden RI Nomor 4, tahun 1995tentang Gerakan Nasional Memasyarakatkan Kewirausahaan

[11] Karimi, S., Biemans, H.J.A., Lans, T., Chizari, M., Mulder, M., (2014). The Impact of Entrepreneurship Education: A Study of Iranian Students' Entrepreneurial Intentions and Opportunity Identification. Journal of Small Business Management

[12] Kirzner, I.M. (1973). Competition and Entrepreneurship.Chicago, IL: University of Chicago 
[13] Koe, W_L.,Sa'ari, J.R., Majid, I.A., Ismail, K., (2012). Determinants of Entrepreneurial Intention Among Millennial Generation. Procedia - Social and Behavioral SciencesVol. 40, pp. $197-208$

[14] Krueger, N.F.(1993), The Impact of Prior Entrepreneurial Exposure on Perceptions and New Venture Feasibility and Desirability. Entrepreneurship Theory and Practice Vol. 18, pp. 5-21

[15] Krueger, J., Norris F. (2000), The Cognitive Infrastructure of Opportunity Emergence. Entrepreneurship: Theory \& PracticeVol. 243, pp. 5-23.

[16] Krueger, N. F., Reilly, M. D., \& Carsrud, A. L. (2000). Competing models of entrepreneurial intentions. Journal of Business Venturing, Vol. 15 No. 5, pp. 411-432.

[17] Krueger NF, Brazeal D, 1994, Entrepreneurial potential and potential entrepreneurs. Entrepreneurship Theory and PracticeVol. 18, pp. 91-104

[18] Liñán. F. \& Chen. Y.W.(2006), Testing The Entrepreneurial Intention Model On A Two-Country Sample, diaksesdarihttp://selene.uab.es/dep-economia-empresa/ recerca/

[19] Linan, F., Santos, F.J. \& Fernandez, J. (2011). The influence of perceptions on potential entrepreneurs||, International Entrepreneurship and Management Journal, 7(3), 373390.

[20] Linan, F., Nabi, G., Krueger, N. (2013). British and Spanish Entrepreneurial Intentions: A Comparative Study. Revista de Economía Mundia/Vol. 33, pp. 73-103

[21] Maresch, D., Harms, R., Kailer, N., Wimmer-Wurmc, B., (2016). The impact of entrepreneurship education on the entrepreneurial intention of students in science and engineering versus business studies university programs. Technological Forecasting \& Social ChangeVol. 104, pp. 172-179

[22] Media Indonesia (30 April 2015). Minimnya Minat Menjadi Pengusaha dalam Editorial Media Indonesia.

[23] Nygren, M. (2016). Developing a Mobile Learning Application for Entrepreneurship Education in Uganda and Zambia. Disertasi Department of Science and Technology Institutionen Linköping University, Sweden

[24] Remeikiene, R., Startiene, G., Dumciuviene, D., (2013)., explaining entrepreneurial intention of university students: the role of entrepreneurial education.

[25] Saadati F, Ahmad Tarmizi R, MohdAyubAF, Abu Bakar K. (2015). Effect of InternetBased Cognitive Apprenticeship Model (i-CAM) on StatisticsLearning among Postgraduate Students. PLOS ONE 10(7): e0129938. doi:10.1371/journal.pone.0129938 
[26] Segal, G., Borgia, \& Schoenfeld, J. (2005). The motivation to become an entrepreneur,International Journal of Entrepreneurial Behaviour \&Research, 11(1), 4257

[27] Shapero A (1975). Who Starts New Businesses? The Displaced, Uncomfortable Entrepreneur. Psychology Today 9: 83-88

[28] Shapero A, Sokol L, (1982). Social Dimensions of Entrepreneurship. In: Kent C, Sexton D, Vesper K (eds.), The Encyclopedia of Entrepreneurship, Prentice-Hall, Englewood Cliffs, pp. 72-90.

[29] Schumpeter, J.A. (1934). The Theory of Economic Development. Cambridge, MA: Harvard University Press

[30] Sondari, M.C., (2014). Is Entrepreneurship Education Really Needed?: Examining the Antecedent of Entrepreneurial Career Intention. Procedia - Social and Behavioral SciencesVol. 115, pp. 44-53

[31] Wang, C. K., \& Wong, P.-K. 2004, Entrepreneurial interest of university students in Singapore. TechnovationVol. 242, pp. 163-172.

[32] Wang, H. Y., \& Wang, S. H. 2010. User acceptance of mobile internet based on the unified theory of acceptance and use of technology: Investigating the determinants and gender differences. Social Behavior and Personality: An International Journa/Vol. 38 No. 3, pp. $415-426$.

[33] Wang, W., Lu, W., \& Millington, J. K. 2011. Determinants of entrepreneurial intention among college students in China and USA. Journal of Global Entrepreneurship ResearchVol. 1 No.1, pp. 35-44 